Workplace Safety Policy:

Past, Present, and Future

Thomas J. Kniesner

John D. Leeth

No. 19/2000 
Thomas J. Kniesner is Krisher Professor of Economics and Senior Research Associate, Center for Policy Research, in the Maxwell School of Syracuse University.

John D. Leeth is Professor of Economics, Bentley College, Waltham, Massachusetts.

The authors are grateful to Kluwer Academic Publishers and the Cato Institute for permission to use material from "Numerical Simulation as a Complement to Econometric Research on Workplace Safety," Journal of Risk and Uncertainty 10(2), March 1995, pp. 99-125; (C) 1995, Kluwer Academic Publishers, Boston; "Improving Workplace Safety, Standards or Insurance?" Regulation 14(4), 1991, pp. 64-70; (C 1991, Cato Institute; "Abolishing OSHA," Regulation 18(4), 1995, pp. 46-56; (C) 1995, Cato Institute; and "Chapter 34. Occupational Safety and Health Administration," Cato Handbook for Congress: 106th Congress, Cato Institute: Washington, DC, 1999, pp. 353-361; (C) 1999, Cato Institute.

The Policy Brief series is a collection of essays on current public policy issues in aging, health, income security, metropolitan studies, and related research done by or on behalf of the Center for Policy Research (CPR) at the Maxwell School of Citizenship and Public Affairs.

Single copies of this publication may be obtained at no cost from the CPR Web site at <http://wwwcpr.maxwell.syr.edu > or from the Center for Policy Research, 426 Eggers Hall, Syracuse, NY 13244-1020.

(C) 2000, Syracuse University. This publication may be distributed freely for educational and researcher uses as long as this copyright notice is attached. No commercial use of this material may be made without express written permission. 


\section{Workplace Safety Policy: Past, Present, and Future}

"We sent our associate Vicki Warren to work undercover at the Washington Regional Bulk Mail Center, and when she saw the appalling conditions the facility's employees must work in, she asked them why they didn't quit. The universal response was that the pay was too good to pass up. The postal workers are, in effect, being paid to risk life and limb.” Jack Anderson, Washington Post, March 7, 1979.

In 1997, 6,218 workers in the United States died from an accident on the job and another 1,833,400 were hurt seriously enough to require at least one day away from work to recuperate. We all want fewer work-related injuries and diseases. How can we design the best public policy to reduce them?

\section{Introduction}

In 1970 Congress passed the Occupational Safety and Health Act

to assure safe and healthful working conditions for working men and women; by authorizing enforcement of the standards developed under the Act; by assisting and encouraging the States in their efforts to assure safe and healthful working conditions; by providing for research, information, education, and training in the field of occupational safety and health, and for other purposes.

To carry out OSHA's functions, Congress created

- the Occupational Safety and Health Administration, commonly known as OSHA, to: promulgate occupational safety and health standards; conduct worker education 


\section{Public Finance Policy Brief}

programs about workplace hazards; inspect work sites under its jurisdiction; investigate complaints by workers; cite employers for noncompliance with OSHA standards; and enforce compliance by levying fines. If a work site is so hazardous that workers are in "imminent danger" of death or serious physical harm, the Secretary of OSHA can petition in U.S. district court to effectively shut down the work site until the danger has been removed. There are also criminal sanctions for willful violation of OSHA standards, unauthorized notice of an upcoming inspection, or falsifying business records required by OSHA.

- the National Institute for Occupational Safety and Health (NIOSH), to gather information and conduct scientific research about workplace injuries and illnesses. NIOSH is now part of the Centers for Disease Prevention and Control (CDC).

- and the National Commission on State Workmen's Compensation Laws, which evaluated the adequacy, equity, and timeliness of the state Workers' Compensation (WC) laws then in effect.

With an annual budget of about $\$ 400$ million, OSHA is about 5 percent the size of the Environmental Protection Agency, another federal agency created by President Richard M. Nixon in 1970, the "Year of the Environment." Nearly all workers in the United States come under OSHA's jurisdiction, with some notable exceptions, including miners, transportation workers, many public employees, and people who are self-employed. OSHA is currently responsible for protecting over 100 million workers at 6 million work sites with the help of only about 2,000 workplace health and safety inspectors. Nevertheless, supporters of OSHA argue that it has significantly improved worker safety over the last 30 years and that a beefed-up enforcement effort would produce even greater improvements.

We examine the available evidence and find little support to the notion that OSHA has effectively reduced accidents and diseases 
in the workplace or that a more vigorous enforcement campaign would be likely to do so. Other policy instruments-tort laws, state Workers' Compensation insurance programs, and research and public education on the causes and consequences of work hazards - now keep workplace deaths and injuries low and can reduce them even more. The wage premiums alluded to by Jack Anderson above, estimated at $\$ 210$ billion per year, that workers receive for accepting job-related health hazards give employers a stronger economic incentive to eliminate workplace health and safety hazards than the $\$ 132$ million per year in fines imposed by OSHA and its state counterparts for violations of workplace safety standards. Because of the heterogeneity of workers and firms, we argue that public policy should expand the economic incentives for workplace safety while allowing firms and workers freedom to discover on their own the best ways to improve workplace safety.

\section{The Failure of OSHA}

Throughout the 1970s and 1980s, workers at the Pymm Thermometer Corporation in Brooklyn, New York, the second largest manufacturer of mercury thermometers in the United States, had no respirators or protective clothing and worked in a building with little outside ventilation. Worst of all were the conditions in a windowless room in the cellar where people recycled mercury from old thermometers. The mercury recycling room was filled with broken glass and noxious fumes from puddles of mercury on the floor. Exposure to mercury can permanently damage vital internal organs such as the brain, lungs, liver, and kidneys.

OSHA originally cited Pymm in 1981 for mercury fume levels five times greater than normal, a level possibly causing severe neurological damage or death. The agency fined Pymm \$1,400 and ordered it to eliminate the mercury fume hazard within six months. Five years after the original elimination order, by which time three additional OSHA inspections had taken place, the company still had not installed the ventilation equipment necessary to reduce mercury exposure to permissible levels. And 


\section{Public Finance Policy Brief}

until a former employee tipped off the inspectors, OSHA was unaware of the mercury recycling room.

The Pymm situation would have continued unchanged, but in 1985 an employee named Vidal Rodriguez broke his elbow at work. After doctors treated Mr. Rodriguez's elbow, they reported to the health departments of both New York City and New York State that Mr. Rodriguez suffered from mercury poisoning. An asthmatic who was no longer able to walk without a cane, Mr. Rodriguez applied for Workers' Compensation benefits and was quickly fired by Pymm. Newspaper accounts of Mr. Rodriguez's case described city and state health departments' concerns over the working conditions at Pymm. The New York City Health Department examined 64 Pymm workers and found mercury levels in the "hazardous" range in about one-third of them, and elevated levels in six workers' children. OSHA still did nothing. Eventually an article describing the agency's dismal enforcement record goaded OSHA into re-inspecting Pymm.

Mr. Rodriguez, who lived only one block from the thermometer plant, met the safety inspectors on the street and described the basement mercury recycling operation. Safety inspectors searched the building for more than a day to find the hidden room. Then, although the inspectors said that the working conditions were a "nightmare," they fined Pymm only $\$ 30,100$ for 16 violations of federal workplace safety and health standards. A year later, two months after a New York City grand jury indicted Pymm and its owners for criminal assault for exposing workers to the high mercury levels, OSHA again inspected the plant and issued another $\$ 75,000$ in citations. Yet it was not OSHA but rather the cumulative impact of criminal prosecution, civil litigation by other workers, an eviction proceeding by the owner of the building (ironically, the City of New York) that finally closed Pymm Thermometer Corporation a few years later.

As we have just seen, OSHA inspectors are often reluctant to initiate actions to close down a company or even to impose dramatic fines when they find serious violations of health and 
safety standards. Other case histories underscore that the situation at the Pymm Thermometer Corporation was far from unique. OSHA inspectors frequently overlook dangerous working conditions and, even when they find serious health and safety violations, inspectors often cannot compel firms to eliminate the hazards discovered. To encourage firms to comply, administrators often slash assessed penalties, which further reduces the already small economic incentives to observe health and safety standards. Firms realize that in the unlikely event they are inspected (recent inspection rates mean that the typical American worker can expect to see an OSHA inspector once every 75 years, or once every 13 years if working in a hazardous job), they can avoid paying meaningful fines by simply agreeing to abide by OSHA's regulations in the future. It is fortunate that OSHA is neither the only nor the main pillar of the U.S. workplace safety policy system.

\section{Overview of the U.S. Workplace Safety Policy System}

OSHA is the most recently constructed pillar of the U.S. safety policy system, which includes the body of tort laws, state Workers' Compensation insurance programs, and the research and public education programs of NIOSH. Reinforcing the four pillars of safety policy are the labor market forces establishing the wage premiums, known as compensating wage differentials, that workers receive for accepting job-related health hazards.

Government safety policy has evolved over time in response to the perceived deficiencies of each previous effort. The initial common law tort system was largely supplanted by states' Workers' Compensation legislation on the grounds that the determination of negligence by courts after the fact left too many workers uncompensated for injury and created too much uncertainty regarding payment of damages. In the 1960s, the purchasing power of Workers' Compensation benefits was eroded by inflation, which outpaced legislated benefit increases. 
Public Finance Policy Brief

The Occupational Safety and Health Act of 1970 also led to the formation of the National Commission on State Workmens' Compensation Laws, which then encouraged states to modify their WC programs and raise their income replacement benefits. The ultimate increases in benefits have raised the cost of buying WC coverage and may have resulted in increased filing of fraudulent benefit claims. Concern over cost containment and safety incentives in the workplace health and safety system are larger today than at any time in recent memory.

Death Rate

(Per 100,000 Workers)

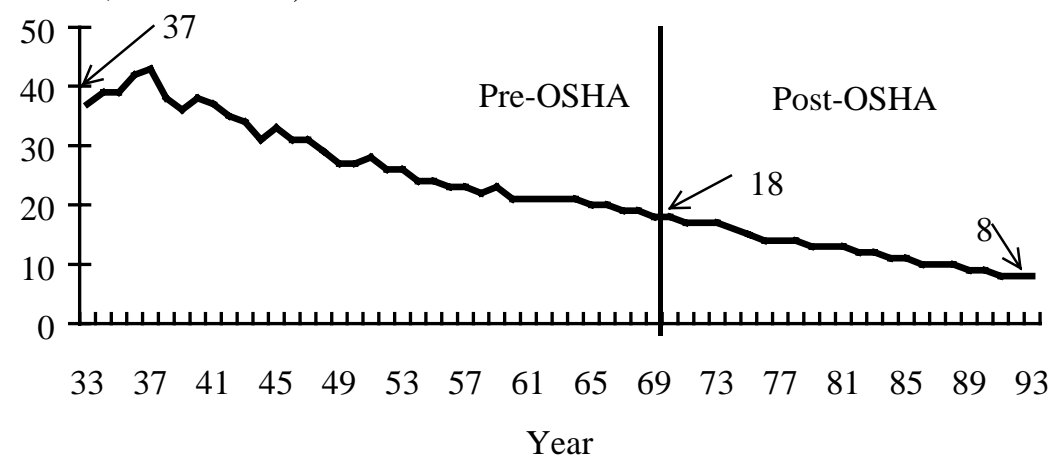

Figure 1. Workplace Fatalities, 1933-1993 (Source: National Safety Council. Accident Facts, 1994 Edition, Itasca, Il: Author.)

\section{Workplace Fatalities}

Figure 1 shows that the frequency of workplace deaths has declined dramatically over the past 65 years. In 1933, for every 100,000 workers there were about 37 workplace fatalities. By 1993 the rate of fatalities had fallen about 80 percent, to 8 per 100,000 workers. The trend line in Figure 1 stops in 1993 because the National Safety Council quit independently calculating workplace fatalities and began relying, instead, on estimates drawn from annual censuses of fatal occupational injuries conducted by the Bureau of Labor Statistics (BLS). For 1997 the BLS estimated that the average worker in the United 
States faced a 5 in 100,000 chance of dying in a work-related accident. As points of reference, the National Safety Council estimated that in 1997 the chance of dying in an accident at home was two times greater (10 in 100,000 annually) and the chance of dying in a motor vehicle accident was over three times greater (16 in 100,000 annually) than the chance of dying in an accident at work.

The two leading causes of work-related deaths in recent years are unlikely to be reduced much by OSHA inspections. Over 40 percent of recent workplace fatalities were from transportation accidents (almost half the fatal transportation accidents occurred on the highway), and about 17 percent of workplace fatalities were from intentional assaults and suicides (for more on "The Changing Character of Fatal Work Injuries" see Toscano and Windau 1994).

Self-employed workers, who are exempt from OSHA jurisdiction, face a much higher chance of dying at work than wage and salary workers, which also has consequences for the effectiveness of OSHA. Although about 9 percent of the workforce is self-employed, they suffered about 20 percent of all workplace fatalities. Differences between the occupational distributions of self-employed and wage and salary workers partially explains the higher fatality rate; compared to wage and salary workers the self-employed are more likely to work in agriculture and construction, relatively high-risk industries, and are less likely to work in manufacturing, a relatively low-risk industry. Self-employed workers are also more likely to be managers of food serving and lodging facilities, and sales supervisors and proprietors, which are occupations where the risk of being a homicide victim during a robbery is high.

\section{Nonfatal Workplace Injuries and IIInesses}

Figure 2 shows nonfatal workplace injuries and illnesses since 1973, which is the first year firms were required to report industrial accidents and diseases. Unlike death rates, injuries and illnesses do not show a marked decline over time. Until the 1990s 


\section{Public Finance Policy Brief}

the pattern of nonfatal workplace injuries and illnesses followed the business cycle closely. Injuries and illnesses rose slightly during the business upturn of the late 1970s, fell during the recession of the early 1980s, and then rose again during the 1980s' macroeconomic expansion. Injuries and illnesses fell during the early 1990s recession and continued to decline even during the business boom of the late 1990s.

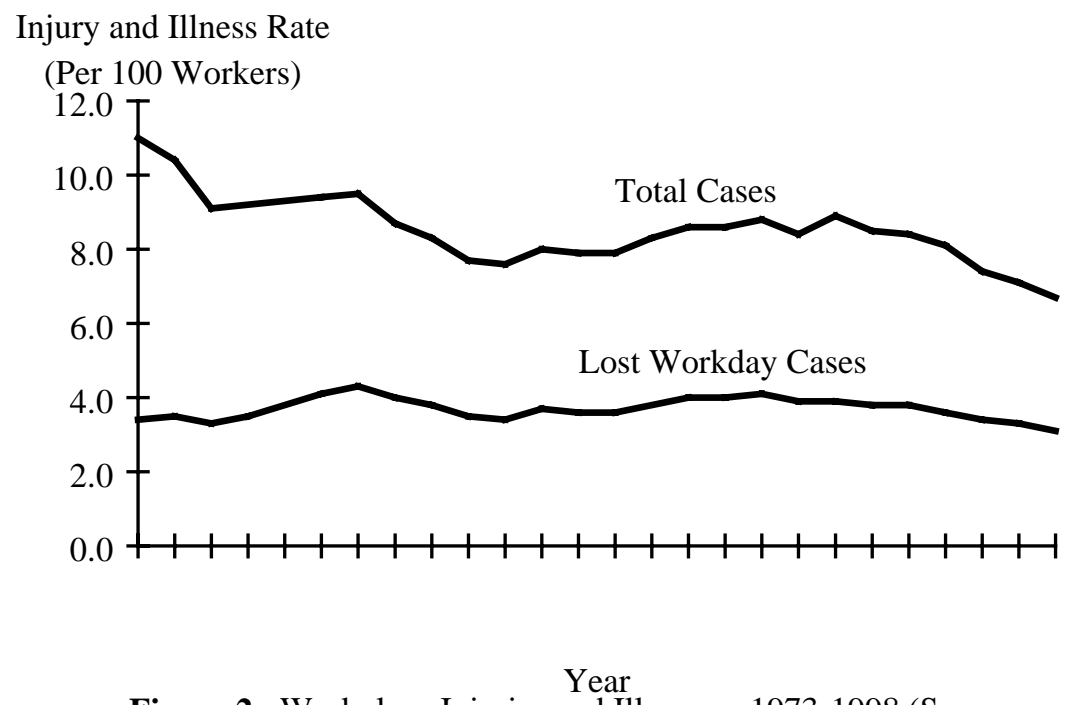

Figure 2. Workplace Injuries and Illnesses, 1973-1998 (Source: U.S. Department of Labor, OSHA, "Occupational Injury and Illness Incidence Rates per 100 Full-Time Workers, 1973-98(2)," at http://www.osha.gov/oshstats/bltable.html.)

Because the rate of workplace deaths has, in fact, fallen by about half since 1970 , from 18 per 100,000 workers in 1970 to 8 per 100,000 workers in 1993, OSHA takes credit for reducing workplace fatalities by 57 percent. Figure 1 shows that the workplace fatality rate began its downward trend well before OSHA, partly fueled by improvements in safety technology and changes in the occupational distribution of labor. To credit OSHA with all the reduction in work-related fatal injuries since 1970 is also misleading. Figure 2 shows no downward trend in either the total frequency of workplace injuries or the frequency of illnesses resulting in at least one lost workday. 
To get a truer picture of OSHA's impact on workplace health and safety, one must control for factors unrelated to OSHA that also affect industrial accidents and diseases. Numerous sophisticated econometric studies have attempted to isolate the effect of OSHA on workplace safety (see Chapter 2 of Kniesner and Leeth 1995a for a review of the research). Although OSHA's supporters cite a few studies suggesting that the agency improves workplace safety, the vast majority of studies have found no statistically significant reduction in the rate of workplace fatalities or injuries due to OSHA. It is thus hard to conclude that OSHA has had any desirable effect on the problem it is supposed to solve.

OSHA is ineffective not because its budget is too small or because it has too few safety and health inspectors. A comparison of the United States and Canada indicates the likely impact of strengthening OSHA enforcement powers. The Canadian system of worker protection against injury is stronger than in the United States. For instance, Quebec province allows workers to refuse hazardous tasks, requires firms to establish joint workplace safety committees with labor, and makes firms initiate accident prevention programs. The Commission de la Santé et de la Sécurité du Travail, Quebec's equivalent of OSHA, also spends over four times more per worker in prevention activities than OSHA. Even with more innovative safety measures and a much greater level of enforcement, the Quebec system of workplace regulation has been no more successful than OSHA in improving worker safety and health (Lanoie 1992).

\section{The Future of Workplace Safety and Health Policy}

Ignoring the mountain of evidence concerning the cost ineffectiveness of the regulatory approach to workplace safety as practiced by OSHA or whether it is even proper to hold OSHA to the economic standard of cost effectiveness, the fact is that OSHA as conceived in 1970 is withering away. Since 1980 the real per worker expenditure on safety standards enforcement by OSHA at both the state and federal levels has fallen by a third. Because the political process is downsizing OSHA at a fairly rapid pace it seems fruitful to discuss some future directions for 
Public Finance Policy Brief

the other three pillars of workplace safety policy in the United States-tort laws, Workers' Compensation, and research and training about workplace hazards - which will continue to be supplemented by the sizable incentives for workplace safety that the labor market creates on its own in the form of compensating wage differentials for accidents and health hazards.

\section{Workers' Compensation Insurance and Experience Rating}

Among other things, the Clinton Administration's failed healthcare reform proposal would have supplanted the state system of Workers' Compensation benefits with federalized medical benefits for workplace accidents and diseases. From the standpoint of workplace safety policy it is fortunate that their initiative failed because it would have reduced the safety incentives of Workers' Compensation by eliminating the current experience rating of WC premiums. By experience rating we mean the process of adjusting insurance prices to reflect individual versus group claims experience. As an example, car insurance is experience rated. The more traffic accidents a person has the more that individual driver will pay for car insurance. Currently, insurance providers completely experience rate WC premiums for only the largest establishments. Very small firms are not experience rated at all, which means that their individual workplace safety record has no impact on the price they pay for WC insurance. Some researchers suggest that the lack of complete experience rating contributes to the positive relationship generally observed between injury rates and WC benefit generosity (Ruser 1985).

On a theoretical basis, it is unclear whether higher WC benefits increase or decrease worker safety. Higher benefits reduce the monetary cost to workers from injury and may encourage them to accept greater hazards on the job. Additionally, workers may be more likely to report accidents and diseases and file claims for disability benefits when benefits are high, so that, even if WC had no influence on workers' acceptance of risk, the rising incentive to file a WC claim would cause a positive relationship between benefits and reported injuries. On the other side of the 
market, if insurance prices are suitably experience rated then higher WC benefits increase firms' incentives to provide safe workplaces. The net impact of WC benefits on workplace safety depends on whether workers or firms respond more greatly to more generous insurance coverage, and the response of firms depends crucially on the degree of experience rating of insurance premiums.

\section{Numerically Simulating Safety Policy Outcomes}

To examine the impact of experience rating we developed a numerical simulation model of labor, insurance, and product markets. By using numerical simulation, we have developed a framework capable of providing an integrated quantitative look at how workers, employers, state governments, and the federal government interact to produce a safe, or in many cases unsafe, working environment. It is impossible to do justice here to the many technical details involved in numerically simulating workplace safety outcomes or to examine an exhaustive set of possible public policy actions. Our book, Simulating Workplace Safety Policy (Kluwer Academic Publishers, 1995), sets out the details and examines U.S. safety policy in depth. It provides a comprehensive overview of how the U.S. economic system, as tempered by government policy, jointly determines employment patterns, wages, and workplace safety levels and how numerical simulations are a research complement to econometric estimation.

Let us now summarize briefly how we use numerical simulation to clarify interactions among workers, employers, and policymakers to understand their connections to workplace safety when there is a Workers' Compensation insurance system involved. The simulations we describe not only support the qualitative conclusion that greater experience rating of Workers' Compensation insurance premiums increases workplace safety but also produce a quantitative impact of experience rating on worker safety in the United States. 


\section{Public Finance Policy Brief}

Our approach to examining the issue of improving workplace safety in the United States is unique. Building on recent theoretical research on how best to describe the economic interactions among many heterogeneous workers and employers, we have developed a numerical description of a labor market where workplaces vary by level of safety and workers vary in their willingness to accept injury risk. Numerical simulation is useful because it allows one to see clearly the avenues through which changes in WC generosity or premium pricing operate to affect workers and their well-being.

Figure 3 presents an overview of the numerical model we have developed and used to guide much of our research on the economics of safety in the workplace. Note the integrated depiction of the linkages among the labor, product, and insurance markets as tempered by government intervention, reflecting safety policy intended to alter labor market outcomes. Unlike other treatments, we realistically allow workers to have differing views about risk and firms to have differing capabilities to produce a safe working environment. Firms unwilling or unable to eliminate all job hazards pay higher wages to attract workers away from firms offering more or complete safety.

Changes in safety policy alter workers' and firms' decisions regarding workplace hazards, in turn reconfiguring the labor market outcomes in Figure 3. In particular, the resulting change in wages creates feedback effects that either reinforce or counteract the direct effects of government programs encouraging safety. Feedback effects occur both within the labor market and between the labor market and other institutions, such as the market for disability insurance. Safety decisions influence the number of WC claims and ultimately the price of WC premiums. Likewise, safety decisions influence production costs and therefore the prices of goods and services. To capture the full set of subtle and not so subtle counterbalancing effects from government policy intended to increase workplace safety, our numerical model examines the complete set of interactions among the labor, insurance, and product markets using what economists currently know quantitatively. 


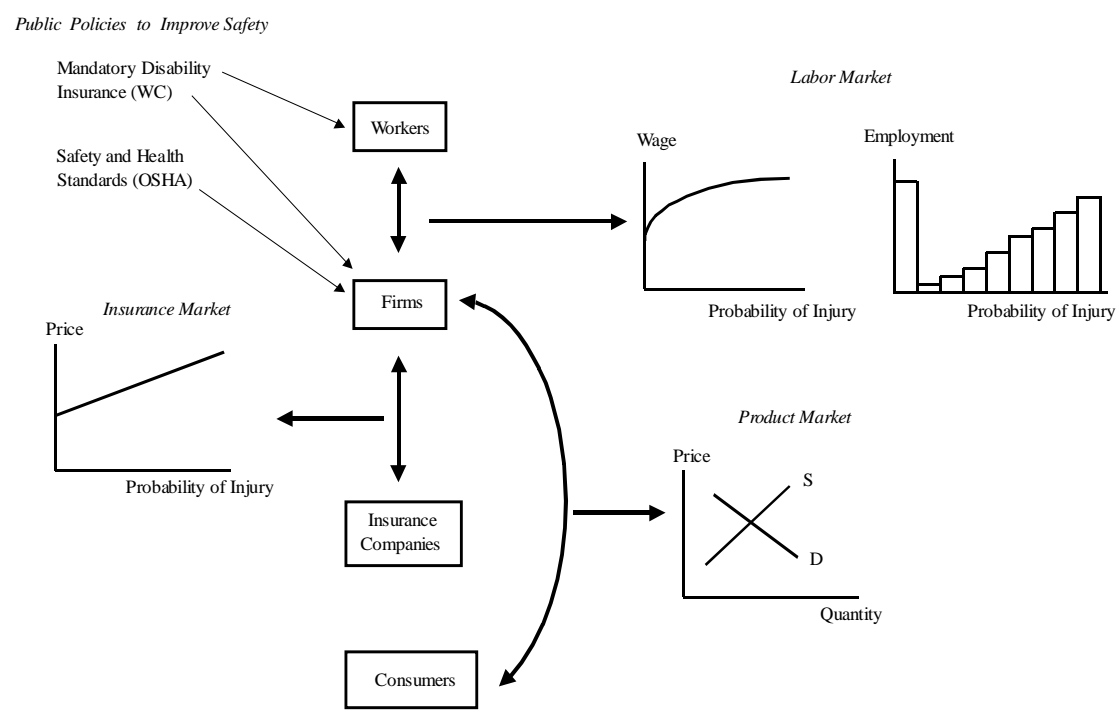

Figure 3. Safety Policy Interactions

\section{Numerical Details of the Simulation Model}

Any method used to solve for labor market outcomes requires specific algebraic equations to represent (i) workers' preferences, also known as utility or well-being, (ii) employers' costs of producing their product, (iii) the cost and effectiveness of safety measures, and (iv) interpersonal and inter-firm differences in attitudes toward risks to health. Figure 4 outlines the general approach used to formalize the mathematical model.

The initial values in Figure 4 are the core set of numbers from which we evaluate policy changes. After positing the initial situation numerically we then chose specific equations to represent how workers' well-being depends on their income and job safety, how firms use labor and other inputs to produce their product, how firms can make the workplace safer, how workers may differ among one another concerning their tolerance for an unsafe workplace, and how firms may differ among one another concerning their ability to make the workplace safer. We used the simplest algebraic equations that are consistent with economic theory. In giving quantitative content to the algebraic expressions 
Public Finance Policy Brief

in our simulation model we relied as much as possible on existing econometric research. Our choices of structural equations and initial parameter values are summarized and justified more fully in Kniesner and Leeth (1995a, 1995c).

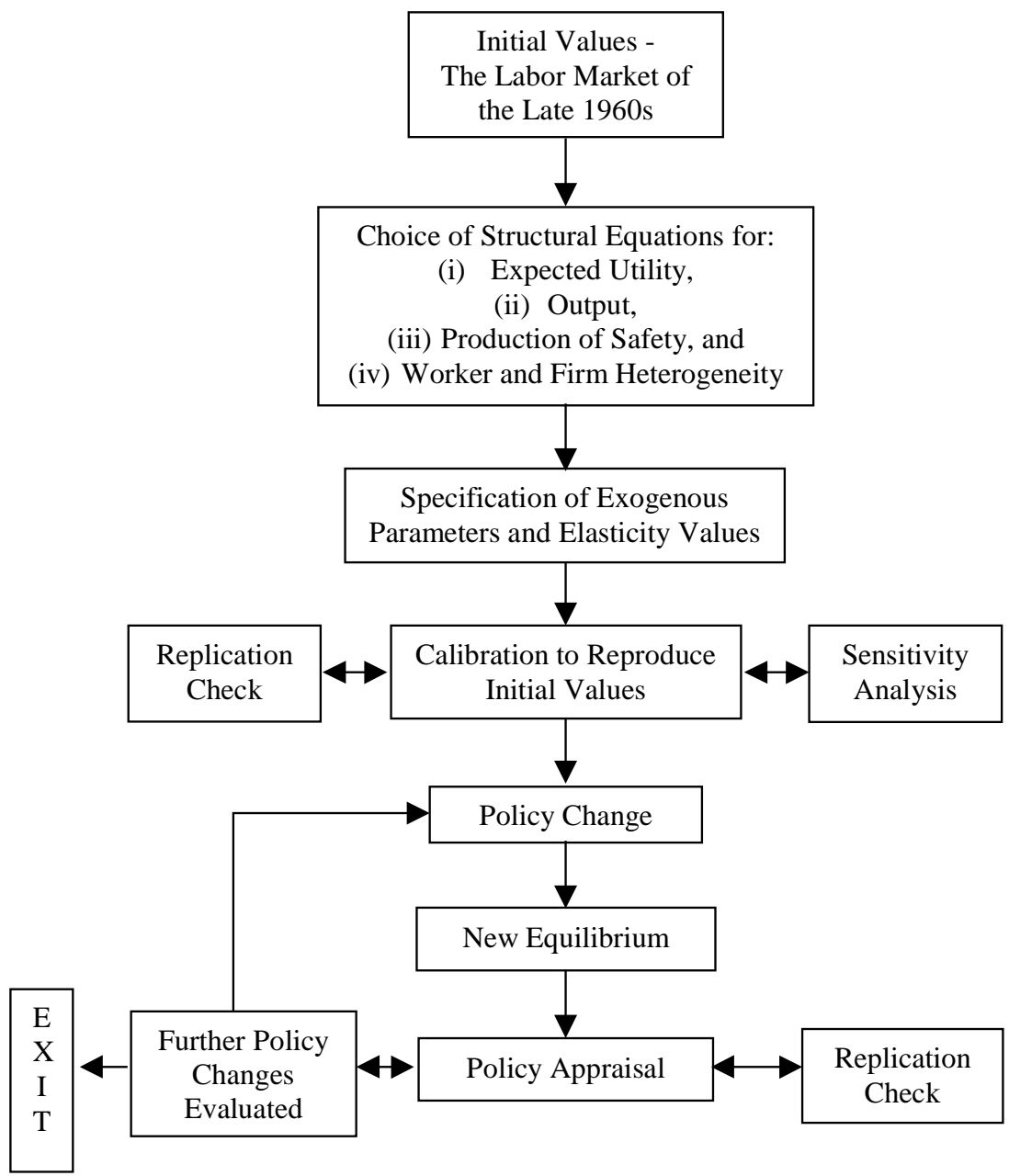

Figure 4. Calibrating the Numerical Model

Calibration. As is typical in numerical simulation, one cannot find every underlying initial numerical value needed by examining existing empirical research. Little information is currently available concerning the relationship between safety programs 
and workplace safety, which is crucial to how the firm produces its product and is an important topic for future research. As a result of the lack of existing statistical research, we calibrated our simulation model using the link between safety program expenditures and workplace safety levels. Calibration means using numerical values for a needed set of coefficients in an algebraic expression so that the overall numerical model reproduces a core set of outcomes. In choosing initial numerical values for our simulation model we reproduced the particular set of wages, employment, and workplace safety outcomes existing before passage of the Occupational Safety and Health Act in 1970 .

\section{The Safety Effects of Experience Rating on Workers' Compensation Insurance}

WC insurance influences workplace safety in two conflicting ways. Workers' monetary concerns if they are injured are reduced if they can expect to receive higher benefits for income loss, which leads them to accept higher risk jobs. In the other direction, higher WC benefits raise firms' costs of workplace injuries, which leads them to improve workplace safety. The more closely insurance companies match WC premiums to workplace safety, the greater are firms' financial incentives to provide safer work environments.

The National Commission on State Workmen's Compensation Laws recommended that insurance providers use experience rating of WC premiums whenever feasible. Historically, WC insurers have not used the accident experience of a small firm to determine the cost of its WC insurance. Instead, insurers have combined the injury statistics for all workers within an industrial class and determined a so-called manual rate for WC coverage. The product of each worker's wage rate and the manual rate for the worker's industrial class summed over all workers determines the total WC insurance premium for a small firm. As firm size increases, insurers pay less attention to the average experience of the industrial class (the manual rate) and more attention to the safety record of the individual firm. Currently, insurance 


\section{Public Finance Policy Brief}

providers completely experience rate WC premiums for only the largest firms.

Some researchers suggest that the lack of complete experience rating contributes to the observation that injury rates are often higher when WC benefits are greater (Ruser 1985). The argument is that under incomplete experience rating, more generous benefits may lead workers to be less careful, and in turn have more accidents, because they have less to lose, and encourage workers to file fraudulent claims or honest claims that were not worth the effort to file when benefits were lower. At the same time, the higher benefits do not create offsetting greater financial incentives to firms to make the workplace safer because benefit generosity is only poorly reflected in the insurance premium the firms pay. However, even with grouped insurance rates, high-risk firms still pay greater total WC insurance premiums than low-risk firms because workplace hazards increase wages, thereby increasing the cost of WC coverage. Higher rates of income replacement then magnify the indirect influence of workplace hazards on firms' insurance costs.

To examine the impact of experience rating we recalculated the outcomes in our numerical simulation model for the situation in which insurance prices completely reflect the expected frequency of injury for each employer. Complete experience rating produces major differences in the calculated labor market effects of WC benefits. Unlike in the base case of incomplete experience rating, when there is complete experience rating of insurance premiums, more generous WC benefits improve workplace safety. Enhanced experience rating tightens the economic link between WC benefits and firms' cost of injuries, which moves firms toward greater safety. Firms' attempts to make the workplace safer dominate any possible offsetting movement of workers toward less safe jobs. Increasing WC benefits to the level recommended by the National Commission on State Workmen's Compensation Laws reduces injuries by 8 percent. In comparison, typical OSHA safety and health standards reduce injuries by 0.3 percent. With complete experience rating of WC 
insurance premiums the safety enhancing effect of WC greatly exceeds that of OSHA.

Summary. At over $\$ 50$ billion, Workers' Compensation insurance is the most influential public policy currently promoting workplace safety. The experience rating of insurance premiums encourages firms to pursue efforts to assure a safe and healthy work environment. Much like the pricing of auto insurance, as the frequency of claims rises the price of insurance increases, thereby penalizing firms for poor safety records. Estimates are that Workers' Compensation insurance has reduced fatal accidents and diseases by 48 percent in the United States (Moore and Viscusi 1990).

Our calculations demonstrate that the link between a firm's safety history and WC insurance premiums could be further strengthened. Other than establishing separate risk pools for small businesses and having insurance premiums better reflect injury severity, though, there is little room to expand significantly the experience rating of $\mathrm{WC}$ premiums.

Although more generous WC benefits for injured workers would also encourage additional workplace safety, evidence indicates that workers are currently satisfied with their WC coverage and unwilling to pay for increased WC benefits (Moore and Viscusi 1990). Therefore, it seems unlikely that there will be a great push for higher WC benefits in the immediate future.

Most states are looking for ways to revamp their WC programs because of escalating costs. We expect WC to move toward clarifying the link between premium levels and workplace safety. Specifically, separating legitimate from illegitimate workplace injury claims is a major problem now confronting WC programs in most states as they struggle to control insurance premium costs. Eliminating fraudulent claims would strengthen the safety incentive in WC by making a closer link between firms' actual workplace safety and the insurance premiums they pay under WC. 
Public Finance Policy Brief

\section{The Legal System}

Many workplace hazards are momentary and require employers and workers to choose the correct course of action quickly to avoid possible harm. Instead of relying on OSHA, policymakers might give more thought to allowing workers to sue their employers for clear-cut cases of negligence. With the no-fault system stemming from WC now in effect, employers are liable for only a portion of the total costs of injuries. Workers receive compensation for medical expenses and income losses, but no compensation for their pain and suffering. Because employers will eliminate workplace hazards if the expected savings from fewer injuries exceed the necessary financial outlays, employers may spend too little for safety under the current limited liability scheme. Permitting workers to sue for pain and suffering in situations where employers show reckless disregard for worker welfare would produce greater safety by making firms bear more of the total costs of injuries.

One major outcome of the Pymm Thermometer Corporation criminal prosecution is that it helped establish that state prosecutors have the right to file criminal charges against employers who endanger their workers, to protect citizens from criminal conduct wherever it occurs; Congress intended to allow states to supplement OSHA civil penalties with their own punishment; and nothing in OSHA precludes enforcement of state criminal laws to address workplace safety. More generally, evidence from product liability settlements suggests that awards for pain and suffering have the effect of deterring injuries (Viscusi 1991). On the negative side, additional legal actions against employers for work-related injuries will increase administrative and court expenses and add uncertainty to compensation for injured workers. To minimize the legal costs, worker suits could be strictly limited to cases of gross or intentional employer misconduct. 


\section{Labor Market Incentives to Workplace Safety}

Empirical studies show wages rise with increases in workplace risk. All else equal, the typical U.S. worker in a job with a likelihood of injury at about the labor market average earns 2-4 percent more than a person working in a totally safe job (see Kniesner and Leeth 1995a, Chapter 3, and 1991b). The added compensation firms must pay to entice workers to accept employment in hazardous work sites gives firms an incentive to expand their investments in safety programs. Employers weigh the benefits of improved safety-smaller compensating wage premiums, lower costs of purchasing WC, fewer work stoppages, and smaller fines for violating OSHA health and safety standards - against the costs of expanded safety programs. In 1998 firms paid more than $\$ 52$ billion for WC and an estimated $\$ 210$ billion for compensating wage differentials to workers for accepting some job hazards. By the end of the fiscal year, fines assessed by OSHA, both federal and state, totaled only $\$ 132$ million. At a ratio of nearly 2,000 to 1 , the economic incentives to improve safety by reducing compensating wage differentials and WC expenses far surpass the safety-enhancing incentives from the relatively small fines imposed by OSHA for violating its standards.

For wage differentials to motivate them, workers need to understand the work-related health risks for which they are being compensated. Evidence indicates that workers do quit hazardous jobs more frequently than relatively safe jobs (Viscusi 1992, Chapter 6). Increases in the probability of an accident also raise quit intentions and job searching, and reduce job tenure. One estimate is that the learning that clarifies job risks may be responsible for about one-third of all worker quits (Viscusi 1979). Workers have fairly accurate information on the frequency of workplace accidents and, even when they do not initially have the correct impression of the hazards they will face on a job, workers reevaluate their beliefs relatively quickly.

Some argue that health-related hazards are more difficult for workers to evaluate than accident-related hazards and, in turn, 


\section{Public Finance Policy Brief}

market mechanisms such as wage premiums for hazardous working conditions do not provide firms with the appropriate motivation to eliminate or reduce health hazards. Workers demonstrate some knowledge of risk by demanding the regularly observed wage premiums for exposure to work-related health risk. However, information users are not willing to compensate private producers of basic research and information enough to cover the underlying costs of creating the knowledge. Therefore, the government will ideally play a role in trying to uncover and disseminate information on the causes and consequences of workplace health hazards.

Workers also reassess job-related hazards based on new information. In one study, chemical workers who were told that they would soon be working with sodium bicarbonate, a safe chemical, reduced their assessment of workplace hazards by 50 percent. Workers who were told that they would be working with either asbestos or TNT increased their assessments of workplace hazards by 200 percent. No workers required extra compensation to handle the safe sodium bicarbonate but workers demanded an extra $\$ 3,000$ to $\$ 5,000$ per year to handle the dangerous asbestos or TNT. No workers said they would quit their jobs because they would be handling sodium bicarbonate but a majority of workers said they would quit because they would be handling asbestos or TNT (Viscusi and O'Connor 1984).

Although information can influence industrial safety by adjusting workers' risk perceptions and their willingness to work in a given setting, the information must be presented in a way best permitting informed judgments. Information overload can occur if precautionary labels present too much data or if too many products have precautionary labels. Warning workers against relatively small risks, such as the risk of cancer from silica (sand), may actually reduce workplace safety by convincing workers that warning labels are irrelevant. A proliferation of hazard warnings in the workplace will prove counterproductive if workers are led to view all activities or products as equally dangerous. 


\section{Policy Recommendations}

We close with specific recommendations for three of the pillars of the U.S. safety policy system: OSHA, Workers' Compensation insurance, and tort law. The reforms we suggest would affect both the federal and state governments and are recommendations we believe are the most basic and likely to have the most impact in the direction of improved safety incentives or cost savings without reducing incentives to have a safer workplace. More indepth discussion of the policy reforms we outline here is presented in Kniesner and Leeth (1991a, 1995b, and forthcoming).

\section{OSHA}

An economically desirable direction for workplace safety policy would be to continue to withdraw resources from OSHA overall, coupled with an immediate revision of its current approach to standard setting, inspections, and fines. In particular, Congress should

- Reduce OSHA's enforcement budget and redirect the funds to $\mathrm{NIOSH}$, which can use the funds to improve workplace safety and health by researching the causes of industrial hazards and diseases and by providing information and guidelines to firms and workers concerning threshold levels of exposure to dangerous substances or workplace practices.

\section{Workers' Compensation}

As we have discussed throughout, state Workers' Compensation insurance provides firms with a powerful economic incentive to improve workplace safety if insurance premiums are adequately experience rated. States should

- Expand experience rating of WC insurance premiums to both small and large firms, and structure rates to reflect both the frequency and severity of injuries. WC premiums have two components: a so-called manual rate, which reflects average 


\section{Public Finance Policy Brief}

claims for the entire industry, and an experience modification factor, which reflects the individual firm's safety record. Primary losses (from high-frequency, low-severity injuries) influence a firm's experience modification factor, depending on what is known as the firm's credibility factor. Small firms have low credibility factors and large firms have high ones, meaning that additional injuries at a small firm will not have as great an impact on its WC premiums as additional injuries at a large firm. Furthermore, a single high-severity injury will not raise a firm's WC premium as much as several lowseverity injuries. To improve workplace safety, the characteristics of WC that mimic a straightforward "tax on injuries" should be strengthened.

- Clarify the link between premium levels and workplace safety. Reducing fraudulent claims will tighten the link between firms' actual workplace safety and the insurance premiums they pay, and thereby strengthen the safety incentive in WC.

\section{Tort Reform}

State tort laws can ease workers' abilities to sue employers for damages and, likewise, provide firms with stronger economic incentives to improve worker safety. States should also

- Allow employees to sue their employers for negligence in cases of gross employer misconduct. WC covers workers against losses caused by industrial accidents and some diseases. Regardless of who is at fault, employers must fully compensate employees for medical expenses and partially compensate them for lost wages caused by work-related injuries. In return, employees forgo their rights to sue employers for full economic damages, including the cost of pain and suffering, when injures occur. With the current limited liability for damages, employers may under-invest in safety programs. Permitting workers to sue for pain and suffering would produce a more appropriate level of safety by forcing employers to bear the complete cost of injuries. The 
fairness of the work-related disability insurance system would also be improved by shifting an important cost of injury to the party responsible. To avoid unduly increasing administrative and court expenses, the right to sue should be strictly limited to instances of gross employer misconduct.

\section{Conclusion}

We all would like safe jobs, just as we would like a clean environment, no automobile deaths, and no crime. Unfortunately, a riskless society is not easy to obtain. People generally are unwilling to accept the severe restrictions on personal freedoms plus the monumental economic expense needed to effect a society free of all risks to personal health and safety.

Unlike the cartoon economist who is ridiculed for knowing the price of everything and the value of nothing, we believe our discussion has demonstrated that we are aware of both the price of greater workplace safety and the value of greater workplace safety. We contend that citizens generally favor a perspicacious government where policy costs and benefits are concerned they want an efficient government, one that does not pay more for something than necessary, including the cost of saving a statistical life via regulation as opposed to other safety programs (for a comprehensive cost-effectiveness study of life-saving policies in the United States see Tengs et al. 1995).

\section{References}

Kniesner, Thomas J. and Leeth, John D. 1991a. "Improving Workplace Safety, Standards or Insurance?" Regulation 14(4): 64-70.

Kniesner, Thomas J. and Leeth, John D. 1991b. "Compensating Wage Differentials for Fatal Injury Risk in Australia, Japan, and the United States." Journal of Risk and Uncertainty 4(1): 75-90. 
Public Finance Policy Brief

Kniesner, Thomas J. and Leeth, John D. 1995a. Simulating

Workplace Safety Policy. Boston, MA: Kluwer Academic Publishers.

Kniesner, Thomas J. and Leeth, John D. 1995b. "Abolishing OSHA." Regulation 18(4): 46-56.

Kniesner, Thomas J. and Leeth, John D. 1995c. "Numerical Simulation as a Complement to Econometric Research on Workplace Safety." Journal of Risk and Uncertainty 10(2): 99-125.

Kniesner Thomas J. and Leeth, John D. Forthcoming. "The Occupational Safety and Health Administration." In Cato Handbook for 107th Congress. Washington DC: The Cato Institute.

Lanoie, Paul 1992. "The Impact of Occupational Safety and Health Regulation on the Risk of Workplace Accidents: Quebec, 1983-87." The Journal of Human Resources 27(4): 643-660.

Moore, Michael J. and Viscusi, W. Kip 1990. Compensation Mechanisms for Job Risks. Princeton, NJ: Princeton University Press.

Ruser, John W. 1985. 'Workers' Compensation Insurance, Experience-Rating, and Occupational Injuries." Rand Journal of Economics 16(4): 487-503.

Tengs, Tammy O. et al. 1995. "Five-Hundred Life-Saving Interventions and Their Cost-Effectiveness." Risk Analysis 15: 369-390.

Toscano, Guy and Windau, Janice A. 1994. "The Changing Character of Fatal Work Injuries." Monthly Labor Review 117(10): 17-28. 
Viscusi, W. Kip. 1979. “Job Hazards and Worker Quit Rates: An Analysis of Adaptive Behavior," International Economic Review, 20(1): 29-58.

Viscusi, W. Kip. 1991. Reforming Products Liability. Cambridge, MA: Harvard University Press.

Viscusi, W. Kip. 1992. Fatal Tradeoffs: Public and Private Responsibilities for Risk. New York: Oxford University Press.

Viscusi, W. Kip. 1998. Rational Risk Policy. Oxford, UK: Oxford University Press.

Viscusi, W. Kip and O'Connor, Charles J. 1984. “Adaptive Responses to Chemical Labeling: Are Workers Bayesian Decision Makers?" American Economic Review 74(5): 942-956. 